The Chittagong Univ. J. B. Sci.,Vol. 4(1 \&2):73-81, 2009.

\title{
OPTIMIZATION OF CONDITIONS FOR EXTRACELLULAR AMYLASE PRODUCTION FROM LISTERIA DENITRIFICANS.
}

\author{
M. N. MAHMUD AND M. N. ANWAR ${ }^{1}$ \\ Department of Microbiology, University of Chittagong, Chittagong -4331, Bangladesh.
}

\begin{abstract}
The foodborne Listeria denitrificans was isolated from degraded rice and studied as an amylase producer. This microorganism showed maximum amylase production at temperature $27{ }^{\circ} \mathrm{C}$ and medium $\mathrm{pH} 7.0$, and on $3^{\text {rd }}$ day during incubation period. Maximum amylase production by the isolate was found in medium containing $3.0 \%$ starch as carbon source and $0.50 \%$ yeast extract as nitrogen source.
\end{abstract}

Key words: Listeria denitrificans, Amylase activity, Factors influence.

\section{INTRODUCTION}

Use of microorganisms in enzyme production is much more economical and environmentally friendly than conventional chemical synthetic methods. They use less energy and utilize renewable resources, and production leftovers are highly biodegradable. They can grow in a wide range of environmental conditions (Trevan et al.2003). Amylases are among the most important enzymes and are of great significance in present day biotechnology. Although they can be derived from several sources such as plants, animals and microorganisms, the enzymes from microbial sources generally meets industrial demands. Microbial amylases could be potentially useful in the pharmaceutical and fine chemical industries if enzymes with suitable properties could be prepared.

With the advent of new frontiers in biotechnology, the spectrum of amylase application has widened in many other fields, such as clinical, medicinal and analytical chemistries. Wide spread application of this enzyme in starch saccharification, textiles, food, brewing and distilling industries very common.

Selection of a suitable strain is the most significant factor in the amylase production process. The environmental factors required for the optimum growth of the microorganism being employed for production may differ from those required for the production of enzymes (Pandey et al.2000). Parameters that

${ }^{1}$ Corresponding author: email- anwarmn51@yahoo.com

$-11$ 
influence microbial amylase production include $\mathrm{pH}$ (Mahmoud 1993, Bormiss et al.1981), temperature (Bormiss et al.1981, Hizukuri et al.1983, Marzan et al. 2001), incubation period (Bormiss et al.1981, Marzan et al. 2001, Rahman et al.1993) and presence of different carbon and nitrogen sources(Mahmoud1993, Guo et al.1988, Lachmund and Ruttkowski 1990, Okolo et al.1995). This paper reports on the screening and identification of a bacterial isolate obtained from degraded rice and also on the determination of its optimum culture conditions involved in maximum production of amylase.

\section{MATERIALS AND METHODS}

\section{Microorganism}

The isolate Listeria denitrificans $\left(\mathrm{NB}_{2}\right)$ was isolated from degraded rice by enrichment technique and purified by repeated pour plate and streak plate methods using nutrient agar (NA) medium.

\section{Screening of the isolates for amylolytic activity}

For primary selection of the isolates, hydrolysis of starch agar plate method was followed. After primary selection, secondary screening of the isolates was made by measuring amylase activity in liquid medium by quantitative method. For in vitro production of amylase by the isolates, three different broth media, namely- Starch yeast extract medium (Adams 1997), Defined salt medium (Almeida et al. 1997) and Standard production medium (Kwan et al. 1993) were used. After secondary Screening, on the basis of their better enzyme activity in broth medium the bacterial isolate $\left(\mathrm{NB}_{2}\right)$ was finally selected for detailed study.

Measurement of enzyme activity

One $\mathrm{ml}$ of culture filtrate was added to $5 \mathrm{ml}$ of $1 \%$ soluble starch prepared in $0.2 \mathrm{M}$ citrate phosphate buffer $\mathrm{pH} 5.8$ and $1 \mathrm{ml}$ of $0.2 \mathrm{M}$ citrate phosphate buffer was taken in a test tube and incubated at $40^{\circ} \mathrm{C}$ for 1 hour (Rahman et al.1993). The amount of reducing sugars released during incubation was measured by Nelson's modification of Somogyi method (Nelson 1944). Enzyme activity was expressed by amount of Glucose released/ml extracted enzyme /unit time $(\mathrm{U} / \mathrm{mL})$.

\section{Biomass yield}

Bacterial biomass was determined by measuring the absorbance at $600 \mathrm{~nm}$ (Henriette et al. 1993). 
AMYLASE FROM LISTERIA DENITRIFICANS

\section{Identification}

The bacterial isolate $\mathrm{NB}_{2}$ was identified on the basis of its morphological, cultural and physiological characteristics. These characteristics were compared with standard description of Bergey's Manual of Determinative Bacteriology (Buchanon and Gibbons, 1974).

Optimization of culture conditions for maximum production of amylase

Effect of incubation period

The effect of incubation periods on the maximum production of amylase by selected isolate was studied. For this, $50 \mathrm{ml}$ of selected medium was taken in each $100 \mathrm{ml}$ conical flask and autoclaved. After cooling the flasks were inoculated and incubated for 24, 48, 72, 96 and 120 hours. The culture was centrifuged at $8000 \mathrm{rpm}$ for $15 \mathrm{~min}$ at $4^{0} \mathrm{C}$.

\section{Effect of medium $\mathrm{pH}$}

To observe the effect of medium $\mathrm{pH}$ on enzyme production, the medium was prepared at different $\mathrm{pH}(4.5,6.0,6.5,7.0$ and 8.5), inoculated and incubated at $37^{\circ} \mathrm{C}$. The effect of medium $\mathrm{pH}$ on biomass characteristics, biomass yield and amylase activity was recorded.

\section{Effect of temperature}

After inoculation the culture medium was incubated at different temperature values such as $10^{\circ} \mathrm{C}, 27 \pm 2^{\circ} \mathrm{C}, 37 \pm 2^{\circ} \mathrm{C}$, and $45 \pm 2^{\circ} \mathrm{C}$ for maximum enzyme production. The effect of temperature on biomass characteristic, biomass yield and amylase production was recorded.

\section{Effect of carbon and nitrogen sources}

Four carbon (starch, rice powder, potato, wheat powder) and five nitrogen sources (malt, yeast extract, ammonium di-hydrogen phosphate, ammonium sulphate and potassium nitrate) were added separately to the medium (Standard Production Medium) and the effect of this carbon and nitrogen sources on the production of amylase, extracellular protein and biomass yield was recorded. To ascertain optimum proportion of suitable carbon and nitrogen sources, the study was carried out with 0.5 to $4 \%$ carbon and 0.025 to $2 \%$ nitrogen sources keeping other experimental conditions at optimum level.

\section{RESULTS AND DISCUSSION}

Primarily, 35 microbial isolates (fungal + bacterial) were isolated from different samples including rice, wheat and bread by enrichment and pour plating 
technique. These isolates were purified, preserved and tested for their amylolytic ability.

\section{Screening of the isolates}

On the basis of their better enzymatic activity in three different broth media, the bacterial isolate $\mathrm{NB}_{2}$ was finally selected for detailed study.

\section{Identification of the selected isolates}

On the basis of their morphological, cultural and biochemical characteristics, the bacterial isolate was found to belong to the genus Listeria. They were provisionally identified as Listeria denitrificans Prevot.

\section{Optimization of culture conditions for maximum production of amylase}

Effect of incubation period on amylase production

The bacterial isolate $\mathrm{NB}_{2}$ exhibited different rate of enzyme activity at different incubation period and maximum at $3^{\text {rd }}$ day (Fig:1). The highest biomass yield was recorded after 5 days of incubation. The $\mathrm{pH}$ of the supernatant was found to range from 5.8 to 6.0. Production of maximum amylase within 48-72 hours of incubation period by bacterial isolate was reported by Sidhu et al. (1997).

\section{Effect of incubation temperature on amylase production}

The bacterial isolate $\mathrm{NB}_{2}$ exhibited maximum enzyme production at $27^{\circ} \mathrm{C}$ (Fig:2) and maximum biomass yield at $37^{\circ} \mathrm{C}$. The color of the supernatant was golden yellow and the change of $\mathrm{pH}$ of the supernatant was found to range from 4.76 to 5.27. Haroun et al. (1993) reported maximum amylase production by Streptomyces strain at $37^{\circ} \mathrm{C}$.

Effect of medium $\mathrm{pH}$ on the production of amylase

The bacterial isolate $\mathrm{NB}_{2}$ exhibited maximum enzyme production at medium $\mathrm{pH}-7.0$ (Fig:3) and maximum biomass yield at medium $\mathrm{pH}$ 6.0. The color of the supernatant was golden yellow and the change of $\mathrm{pH}$ of the supernatant was recorded to range from 5.2 to 6.11. The isolate exhibited turbid growth with sedimentation at different medium $\mathrm{pH}$. The optimum $\mathrm{pH}$ of the bacterial isolate $\mathrm{NB}_{2}$ was recorded to be 7.0 which is closely related to the observations of Hisaka et al. (1993) in Flavobacterium odoratum.

Effect of carbon and nitrogen sources on the production of amylase

The $\mathrm{pH}$ values of the culture supernatant of the bacterial isolate $\mathrm{NB}_{2}$ were found to vary from 5.76 to 7.15 and the colour was also found variable (transparent, golden yellow, deep brown to red oxide) with different carbon and 


\section{AMYLASE FROM LISTERIA DENITRIFICANS}

nitrogen sources. Highest biomass yield was recorded with starch and malt when used as carbon and nitrogen sources, respectively. The bacterial isolate exhibited highest amylase production in starch and yeast extract containing medium (Fig:4) and also showed that the optimum concentration of starch and yeast extract for maximum enzyme production were $3.0 \%$ and $0.50 \%$, respectively (Fig:5). Maximum amylase production by Aspergillus fumigatus was reported when $0.25 \%\left(\mathrm{NH}_{4}\right)_{2} \mathrm{HPO}_{4}$ and $4 \%$ starch were added in the growth medium (Cherry et al. 2004).

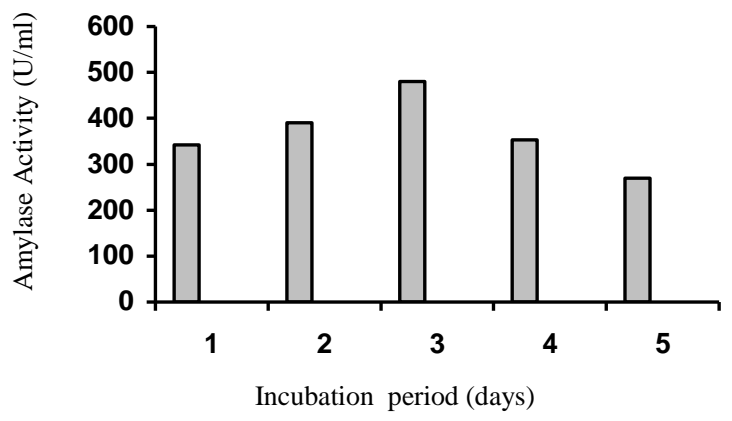

FIGURE 1. EFFECT OF INCUBATION PERIOD ON THE PRODUCTION OF AMYLASE BY THE ISOLATE L. DENITRIFICANS.

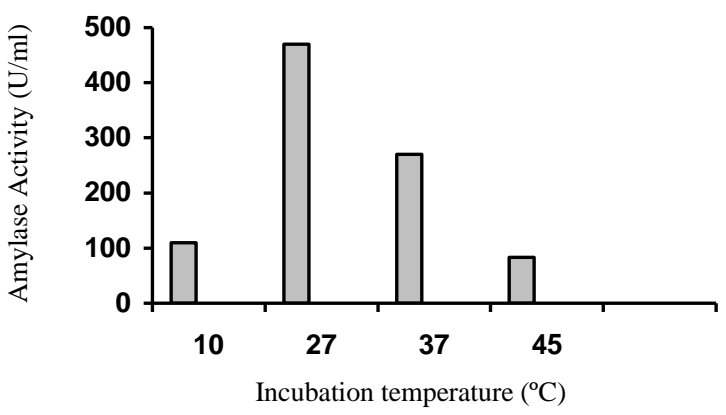

FIGURE 2. EFFECT OF INCUBATION TEMPERATURE ON THE PRODUCTION OF AMYLASE BY THE ISOLATE L. DENITRIFICANS. 
MAHMUD AND ANWAR

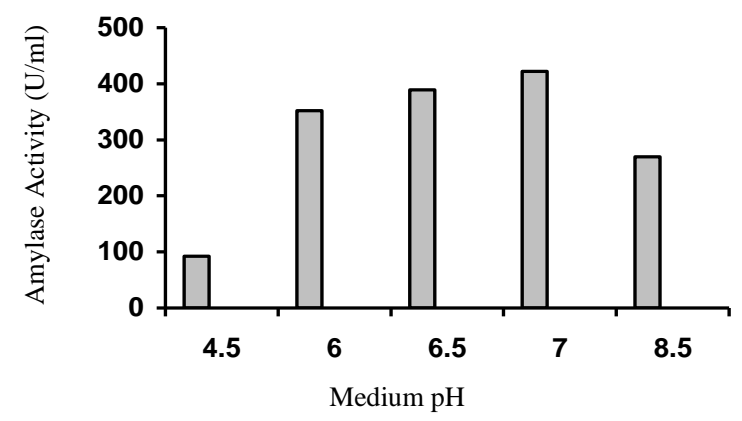

FIGURE 3. EFFECT OF MEDIUM PH ON THE PRODUCTION OF AMYLASE BY THE ISOLATE L. DENITRIFICANS.

Nitrogen source

$\longrightarrow$ Malt $\longrightarrow$ Yeast extract $\square$ - NH4H2PO4 $\rightarrow\left(\mathrm{NH}_{4}\right) 2 \mathrm{SO} 4 \rightarrow$ KNO3

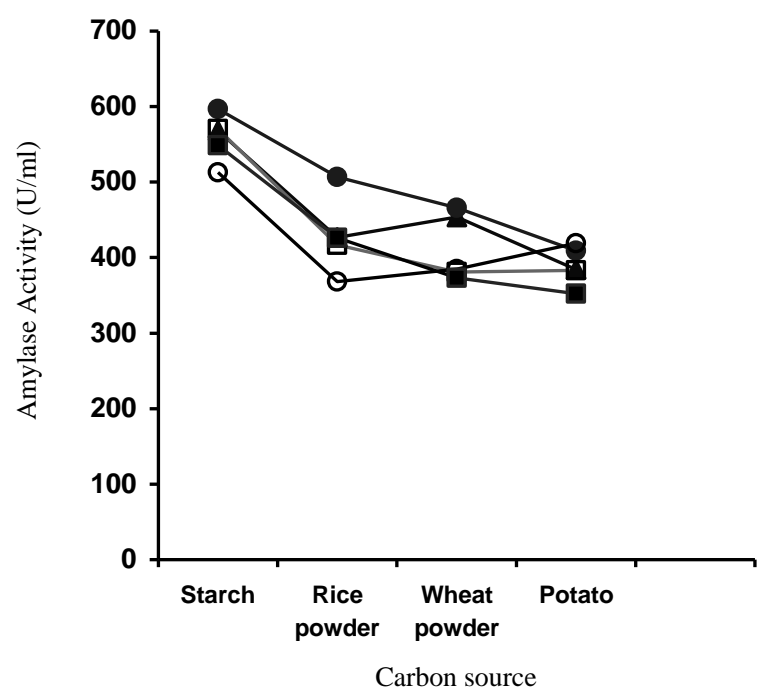

FIGURE 4. EFFECT OF CARBON AND NITROGEN SOURCES ON THE PRODUCTION OF AMYLASE BY THE ISOLATE L. DENITRIFICANS. 


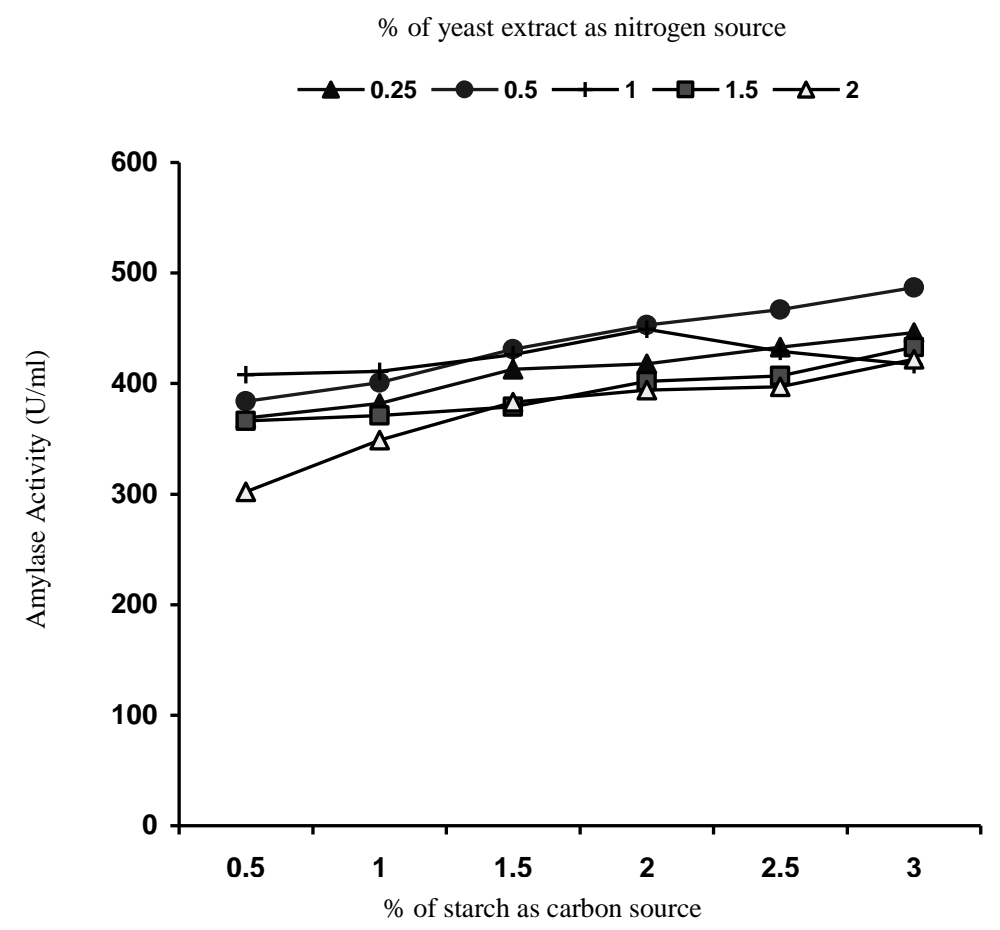

FIGURE 5. EFFECT OF CONCENTRATION OF STARCH \& YEAST EXTRACT ON THE PRODUCTION OF AMYLASE BY THE ISOLATE L. DENITRIFICANS.

\section{REFERENCES}

ADAMS, P.R.1997. Growth and amylase production in Sporotrichum thermophile Apinis. Biotech. Appl.Biochem.26:169-170.

ALMEIDA, E.M.D.S., MIZUTA, K. AND GIGILO, J.R. 1997. Pycnoporus sanguineus : A novel source of $\alpha$-amylase. Mycol. Res. 101:188-190.

BORMISS, R., SCHMIDT, D., GORGES, E., RUFTOFF, H.,TAEUFEL, A., LIETZ, P., STEFFEN, H., WOLFGANY AND GERGS, U. 1981. Enzyme mixture for saccharification of grain mash. Ger(East) D.D. 152:142.

BUCHANON, R.E. AND GIBBONS, N.E. 1974. Bergey's Manual of Determinative bacteriology. The Williams and Wilkins Co, Baltimore. Pp- 595-596. 
CHERRY, H.M., HOSSAIN, M. T. AND ANWAR, M. N. 2004. Extracellular glucoamylase from the isolate Aspergillus fumigatus. Pak. J. of Bio Sci. 7(11):1988-1992.

GUO, Y., HAUNG, L., ZHAO, M., CHEN, H., PENG, X., LUO, G., AND LIXUAN, L. 1988. Production of glucoamylase by immobilized cells. II. Conditions for batch fermentation and semicontinuous fermentation. Shipin Yu Fajiao Gongye. 2: 28-31.

HAROUN, B.M.E.L., ZAWAHRY, Y. A., EI-SAID, M. A. AND GHALY, M. F. 1993. $\alpha$-Amylase isolated from Streptomyces lipmanii-ZAG 37. Egypt. J. Microbiol. 28(3):311-319.

HENRIETTE, C., ZINEBI, S., AUMAITRE, M.F., PETITDEMANGE, E. AND PETITDEMANGE, H. 1993. Protease and lipase production by a strain of Serratia marcescens. J. Industrial Microbiol. 12: 129-135.

HISAKA, S., ABE, J., TAKAHASHI, Y. AND NAKAMURA, N. 1993. Isoamylase, its manufacture with Flavobacterum odoratum and manufacture of sugars with isoamylase. Jpn. Kokai Tokyo jp. 05:227,957.

HIZUKURI AND SUSUMU. 1983. Aspergillus strains and their use to produce D-glucose from starch. Eur. Pat. Appl. Ep. 134:546.

KWAN, H. S., SO, K. H., CHAN, K.Y. AND CHENG S.C. 1993. Production of thermotolerant $\beta$-amylase by Bacillus circulans. World J. of Microbiol. and Biotech. 9:50-52.

LACHMUND, A. AND RUTTKOWSKI, E. 1990. Investigations on the expression and regulation of the $\alpha$-amylase gene from Aspergillus oryzae. DECHEMA Biotechnol. Conf. 4:399-402.

MAHMOUD, A.L.E. 1993. Different factors affecting growth and amylase production by fungi inhabiting poultry feeds. J. Basic Microbiol.33(3):187-192.

MARZAN, L.W., MANCHUR, M.A., HOSSAIN, M.T. AND ANWAR, M. N. 2001. Production of protease and $\alpha$-amylase by Fusarium poae. Bangladesh J. Microbiol. 18:127-134.

NELSON, N. 1944. A photometric adaptation of the Somogyi method for the determination of glucose. J. Biol. Chem. 153: 375-380.

OKOLO, B.N., EZEOGU, L.I. AND MBA, C. N. 1995. Production of raw starch digesting amylase by Aspergillus niger grown on native starch sources. J. Sci. Food Agric. 69:109-115. 
AMYLASE FROM LISTERIA DENITRIFICANS

PANDEY, A., NIGAM, P., SOCCOL, C.R., SOCCOL, V. T., SINGH, D. AND MOHAN, R. 2000. Advances in Microbial amylases. Biotechnol. Appl. Biochem. 31:135-152.

RAHMAN, A.K.K.M.S., RAHMAN, M.F., NATH, P.K., HOQ, M.M. AND HOSSAIN, M. 1993. Glucoamylase activity of some selected strains of Aspergillus niger and A. oryzae. Bangladesh J. Microbiol. 10: 107110.

SIDHU, G.S., SHARMA, P., CHAKRABARTY, T. AND GUPTA, J.K. 1997. Strain improvement for the production of a thermostable $\alpha$-amylase. Enzyme and Microbial Technology. 21:525-530.

TREVAN, M D., BOFFEY, S., GOULDING, K A. AND STANBURY, P. 2003. Biotechnology: The biological principles. $19^{\text {th }}$ reprint. Tata, Mc, GrawHill pub. Co Ltd.New Delhi, India. Pp.160-162.

Manuscript received on 18.6.09; Accepted on 26.6. 08

The Chittagong University Journal of Biological Sciences, Vol.4 ( 1 \& 2): Page No : 73-81 